\title{
Microbiological Evaluation of the Effectiveness of Sewage Sludge Sanitization with Solar Drying Technology
}

\author{
Zbigniew Paluszak, ${ }^{1}$ Krzysztof Skowron, ${ }^{1,2}$ \\ Małgorzata Sypuła, ${ }^{1}$ and Karolina Jadwiga Skowron ${ }^{1}$ \\ ${ }^{1}$ Department of Microbiology, Faculty of Agriculture and Biotechnology, University of Technology and Life Sciences in Bydgoszcz, \\ Bernardyńska 6-8, 85-029 Bydgoszcz, Poland \\ ${ }^{2}$ Department of Microbiology, Faculty of Pharmacy, Nicolaus Copernicus University in Torun, Collegium Medicum of L. Rydygier in \\ Bydgoszcz, M. Skłodowskiej-Curie 9, 85-094 Bydgoszcz, Poland
}

Correspondence should be addressed to Zbigniew Paluszak, paluszak@utp.edu.pl

Received 28 May 2012; Accepted 4 September 2012

Academic Editor: Manickavachagam Muruganandham

Copyright ( 2012 Zbigniew Paluszak et al. This is an open access article distributed under the Creative Commons Attribution License, which permits unrestricted use, distribution, and reproduction in any medium, provided the original work is properly cited.

\begin{abstract}
The aim of study was to estimate the sanitization effectiveness of the sludge solar drying process carried out on technical scale in Poland based on the inactivation of bacteria and parasite eggs. Sewage sludge samples inoculated with Escherichia coli, Salmonella Senftenberg $\mathrm{W}_{775}$ and enterococci and perlon bags containing Ascaris suum eggs were placed inside the carriers fixed in the dried sludge pile and on the shovels and frame of the sludge turner. The number of reisolated microorganisms was determined with MPN method and the percentage of invasive A. suum eggs-with the microscope counting. On the basis of regression equations, the theoretical survivability and elimination rate of bacteria and parasite eggs were calculated. Experiment showed low hygienization efficiency of solar drying method. The theoretical survival time was 46-104 days in summer and 90-98 days in winter for S. Senftenberg $\mathrm{W}_{775}$ and, respectively $42-55$ and 71-148 days for E. coli, depending on the carriers location. Enterococci were able to survive for 52-168 days in summer and in winter its number increased. The decrease in the percentage of invasive A. suum eggs was almost not observed. Results indicated that solar drying is a technology, which does not guarantee biosafety of product.
\end{abstract}

\section{Introduction}

Growing effectiveness of sewage treatment technologies results in a considerable increase in generated sewage sludge [1]. The dry matter of stabilized municipal sewage sludge is expected to amount to $662,000 \mathrm{Mg}$ in Poland in 2015.

A considerable number of viruses, bacteria, and intestinal parasites may be present in sewage derived from hospitals, slaughter houses, and animal farms [2-5].

According to Bień [6], Sahlström [7], Pepper et al. [8], and Sun et al. [9], bacteria of the genera: Salmonella (about 1,700 types), Shigella (4 species), Escherichia coli, Vibrio cholerae, Mycobacterium tuberculosis, Pseudomonas aeruginosa, Clostridium perfringens, Bacillus anthracis, Listeria monocytogenes, Streptococcus faecalis, and Proteus vulgaris and viruses of the genera Enterovirus (67 types), Rotavirus, Parvovirus, and Adenovirus (31 types) are frequently isolated from sewage sludge.
Of various methods of sewage treatment in Poland, those consisting in physicochemical processing, including drying, are developing dynamically. Conventional drying allows considerable reduction in the mass and volume of produced sludge, but it generates high costs resulting from the facility operation and causes a substantial emission of gaseous pollutions to the atmosphere.

The unconventional, low-temperature technology of solar drying of sewage sludge is prospective from the economic and ecological point of view [10].

Due to sanitary and epidemiological reasons, it is necessary to establish biological and microbiological methods which allow constant monitoring of sewage sludge sanitization effectiveness in solar drying process.

The aim of this study was to estimate the sanitization effectiveness of the sludge's solar drying process conducted on technical scale in Poland, based on the inactivation kinetics of indicator bacteria and selected parasite eggs. 


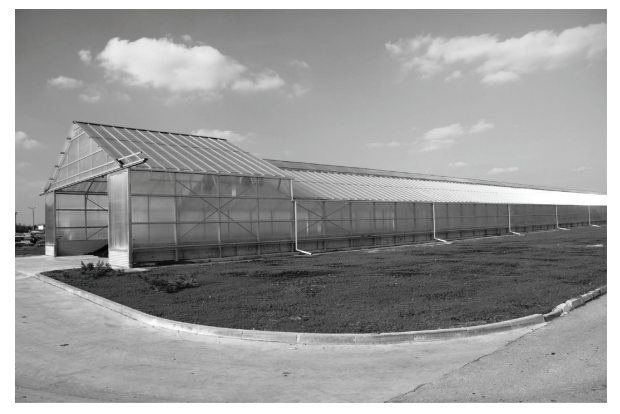

FIgURE 1: Solar drying plant in Iława.

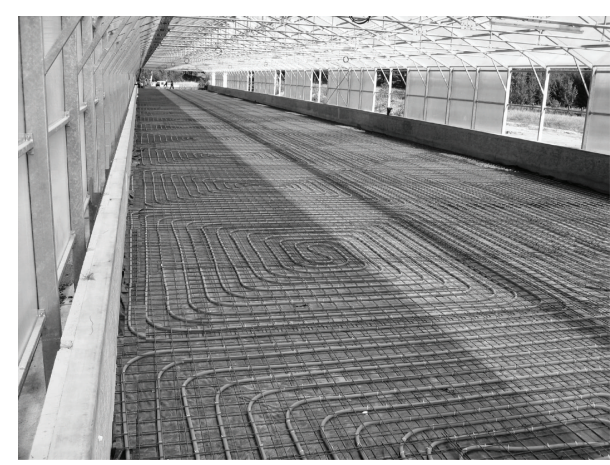

Figure 2: Heating floor system in drying hall.

\section{Material and Methods}

The study was carried out in a solar drying plant of sewage sludge in north Poland in 2 research cycles, in summer and winter.

\subsection{Description of the Examined Technology of Sludge Drying.} The solar drying plant is a system used commercially and it works in full scale at the waste water treatment plant in Iława. This sewage sludge drying installation consists of drying halls similar to green houses with gable roof (Figure 1). The construction of the drying hall is made of zinc-coated steel and covered with polycarbonate plates. The dimensions of the drying hall are $120 \mathrm{~m}$ length, $12 \mathrm{~m}$ width, and $6 \mathrm{~m}$ height.

The described solar drying plant is a hybrid installation. The main principle of the drying operation is the solar effect, but also the heating floor system (Figure 2) is exploited for water evaporation from sewage sludge. The heating floor additionally supports the drying process and the heat necessary for its functioning is made by a heating pump which recovers energy from the treated sewage through the collector in secondary clarifier.

The solar drying plant is located next to the building of mechanical sludge dewatering station, from where dehydrated sludge is transported into the hall by the transporter system. Inside the drying hall mechanically dewatered sludge is spread with an even layer on the concrete floor and then transported, aerated, granulated and moved to the end of the hall by the nave turning sludge device (Figure 3 ). The

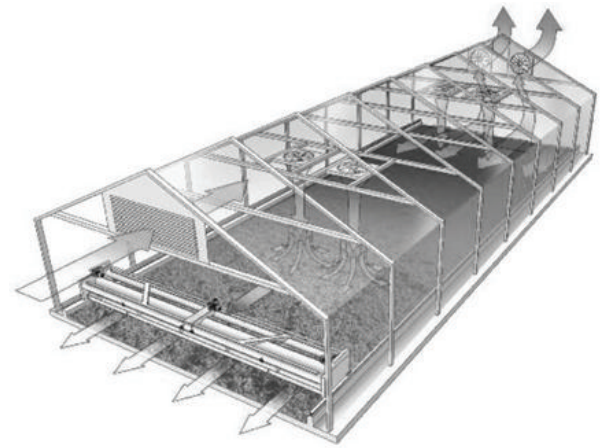

FIGURE 3: Scheme of solar drying plant with nave turning sludge device (http://www.huber.de/).

automatic ventilation system, which consists of mechanical ventilators inside the hall and the automatically opened window at the top of the roof, ensures and improves water evaporation and humidity removal outside the drying hall.

The annual plant capacity is $3,500 \mathrm{t}$ of sewage sludge whose dry matter content at the beginning of the process is up to $20 \%$ and after drying $85-90 \%$. The studies conducted so far show that under the climatic conditions prevailing in Iława, using solar energy allows to evaporate on average $988 \mathrm{~kg}$ of water from $1 \mathrm{~m}^{2}$ of active surface of the dryer within a year. The drying hall with a total drying area of $1,440 \mathrm{~m}^{2}$ provides evaporation of about 1,422 tons of water.

Solar sludge drying is currently the cheapest method of getting rid of water from the sludge. For example, 1 tone of water evaporation in the solar drying system requires using about 20-30 kWh, while in conventional drying system based on traditional fuels above $800 \mathrm{kWh}$.

2.2. Material for the Study. The material for the study was sewage sludge after mechanical dewatering to a dry matter content of $10 \%$ to $20 \%$. The presence of native Salmonella, bacteria E. coli, and enterococci was examined in collected sludge samples. Also the proportion of dry matter and dry organic matter, $\mathrm{pH}$, and the content of basic macroelements and heavy metals were determined in the sludge.

\subsection{Experimental Design. The study was conducted in 2} cycles, summer and winter. In each cycle, 3 replications were made for each location of the carrier.

The experiment was carried out using carriers in the form of perforated cylinder with a threaded lock.

Samples of municipal sludge with a weight of $25 \mathrm{~g}$ were contaminated with $1 \mathrm{~mL}$ of the suspension of Escherichia coli, bacilli Salmonella Senftenberg $\mathrm{W}_{775}$ and enterococci and placed in the carriers. Also perlon bags containing live eggs of Ascaris suum were placed inside the carriers. Then they were closed and fixed in selected points (in the pile of dried sludge at the end of the hall, as well as on shovels and frame of the sludge turner).

From each location, 3 carriers were collected for the study after $7,14,21$, and 28 days, respectively. 
TABLE 1: Applicable reference methods of municipal sewage sludge research [11].

\begin{tabular}{|c|c|c|}
\hline Number & Parameter & Method \\
\hline (1) & $\mathrm{pH}$ & Electrometric determination in water solution \\
\hline (2) & Dry matter content & Drying at $105^{\circ} \mathrm{C}$, weighing \\
\hline (3) & Organic substance content & Roasting at $600^{\circ} \mathrm{C}$, weighing \\
\hline$(4)$ & Total nitrogen content & Mineralization in acid $\mathrm{pH}$ with addition of catalyst \\
\hline (5) & Ammonium nitrogen content & $\begin{array}{l}\text { Distillation of ammonia and determination with } \\
\text { spectrophotometric method }\end{array}$ \\
\hline (6) & Total phosphorus content & $\begin{array}{l}\text { Mineralization to phosphorus (V) and determination with } \\
\text { spectrophotometry }\end{array}$ \\
\hline (7) & Calcium and magnesium content & $\begin{array}{l}\text { Mineralization with acid mixture and determination with } \\
\text { atomic spectrometry }\end{array}$ \\
\hline (8) & $\begin{array}{l}\text { Heavy metal content: lead, cadmium, mercury, } \\
\text { nickel, zinc, copper and chromium }\end{array}$ & $\begin{array}{l}\text { Atomic absorption spectroscopy after mineralization in aqua } \\
\text { regia or concentrated acids }\end{array}$ \\
\hline
\end{tabular}

2.4. Monitoring of Climatic Conditions. During the experiment, the following parameters were monitored: humidity and temperature in the drying plant (with the use of the hygrothermometer), the temperature in the pile (with the use of the in-pile thermometer), the intensity of diffuse solar radiation coming to the horizontal plane of the drying plant roof (with the use of pyranometer), and the outside microclimatic conditions (the climatic station data). Monitoring was conducted according the methods commonly applied in meteorology.

2.5. Physicochemical Analyses. The physicochemical analysis of the dried sludge parameters was made at each sampling time. It involved the assessment of dry matter and organic dry matter content, $\mathrm{pH}$, the content of fertilizer components (total and ammonium nitrogen, total phosphorus, calcium, and magnesium), and heavy metals (lead, cadmium, mercury, nickel, zinc, copper, and chromium).

Physicochemical analyses of the sludge were carried out using the referential methods described in Appendix 5 to the ordinance of the Ministry of the Environment of 13rd July 2010 on municipal sewage sludge (Dz.U. 2010 nr 137 poz. 924) [11]. The applied methods are presented in Table 1.

2.6. Microbiological Analyses. For contamination of the experimental material, suspension of Salmonella Senftenberg $\mathrm{W}_{775}$, bacteria E. coli, and enterococci were used.

From 24-hour pure cultures of the tested microorganisms on nutrient agar, bacterial suspensions in $0.90 \%$ physiological salt solution with a density of $10 \mathrm{McF}(\sim 3.0 \times$ $10^{9} \mathrm{cfu} \times \mathrm{cm}^{-3}$ ) were prepared.

The number of microorganisms isolated from the carriers submitted to solar drying process at successive times was determined based on the MPN method in the three-tube design.

In the process of Salmonella isolation, 1\% buffered peptonic water was used for initial multiplication (incubation for 24 hours at $37^{\circ} \mathrm{C}$ ). Selective enrichment was conducted on the Rappaport medium (incubation for 24 hours at $43^{\circ} \mathrm{C}$ ). BPLS agar was used as the solid growing medium (incubation for 24 hours at $37^{\circ} \mathrm{C}$ ). Final identification was carried out using the $\mathrm{PCR}$ reaction for detecting the fragment invA [12]. To $5 \mu \mathrm{L}$ of isolated DNA $20 \mu \mathrm{L}$ mastermix was added, composed of distilled water $(8.85 \mu \mathrm{L}), 10 \mathrm{x}$ PCR buffer $(2.5 \mu \mathrm{L}$; Bioline, cat. no. BIO-37030), magnesium chloride (1.50 $\mu \mathrm{L}-25 \mathrm{mM}$; Bio-Rad, cat. no. 170-8872), dNTP's ( $5 \mu \mathrm{L}-1 \mathrm{mM}$; Bio-Rad, cat. no. 170-8874), primer 139 (5' GTGAAATTATCGCCACGTTCGGGCAA 3' $1 \mu \mathrm{L}-$ $10 \mu \mathrm{M})$, primer 141 (5' TCATCGCACCGTCAAAGGAACC 3' $1 \mu \mathrm{L}-10 \mu \mathrm{M})$, and Taq polymerase $(0.15 \mu \mathrm{L}-5 \mathrm{U} / \mu \mathrm{L}$; BioRad, cat. no. 170-8870). The initial denaturation of DNA was conducted at $95^{\circ} \mathrm{C}$ for 1 minute. Then 38 cycles were comprising of denaturation $\left(30\right.$ seconds at $\left.95^{\circ} \mathrm{C}\right)$, annealing (30 seconds at $64^{\circ} \mathrm{C}$ ), and elongation $\left(30\right.$ seconds at $72^{\circ} \mathrm{C}$ ). The last stage of the PCR reaction was the final elongation carried out for 4 minutes at $72^{\circ} \mathrm{C}$. Electrophoresis was carried out in 1.8\% agarose gel (Bio-Rad, cat. no. 151-0450) at the voltage $5 \mathrm{~V} \times \mathrm{cm}^{-1}$ for 60 minutes and dyed with ethidium bromide (Bio-Rad, cat. no. 161-0433).

To determine E. coli number, the MacConkey liquid medium was used (incubation for 24 at $43^{\circ} \mathrm{C}$ ). Then the material was sieved on the solid medium ENDO agar (incubation for 24 hours at $43^{\circ} \mathrm{C}$ ). The final identification was carried out based on the set of biochemical tests API 20E.

Enterococci determination was carried out using broth with glucose and azide (incubation for 24 hours at $37^{\circ} \mathrm{C}$ ) and agar with kanamycin (incubation for 24 hours at $37^{\circ} \mathrm{C}$ ). The final identification was carried out based on the Phadebact D-Strep Test.

2.7. Parasitological Investigation. Ascaris suum eggs were obtained from uteruses of sexually mature females and placed on Petri dishes filled with saline solution. Suspension in volume of $1 \mathrm{~mL}$ with a density from $1.0 \times 10^{3}$ to $6.0 \times 10^{3}$ eggs $\times \mathrm{cm}^{-3}$ was introduced to each perlon bag and used for experiment. The bags collected during the study were opened and placed on Petri dishes with tap water. Incubation lasted for 28 days at $28^{\circ} \mathrm{C}$. The percentage of invasive eggs was determined with the microscope counting method. 


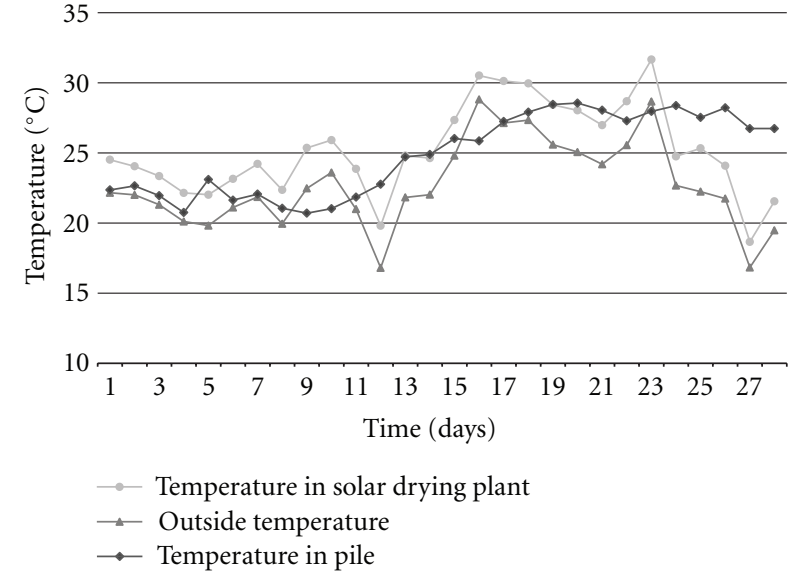

Figure 4: The course of temperature during the summer cycle (July).

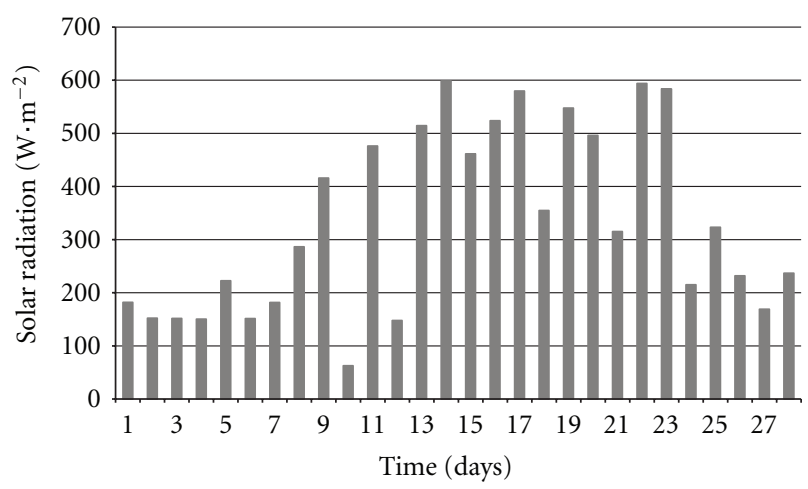

FIGURE 5: The course of insolation during the summer cycle (July).

2.8. The Statistical Analysis of the Results. The obtained results were analyzed statistically in the program SAS 9.2 PL. On the basis of regression equations, the theoretical times of survival and elimination rates of the studied bacteria and parasite eggs were determined. The significance of differences between the theoretical survival rate of individual microorganisms in respect of the season and the location of the carrier was estimated based on Tukey's test at the significance levels $P \leq 0.05$ and $P \leq 0.01$.

\section{Results and Discussion}

3.1. Climatic Conditions. The effectiveness of sludge drying in solar drying plants is very closely connected with climatic conditions.

The detailed course of the analyzed indexes of microclimate in the summer cycle was presented in Figures 4, 5, and 6.

In the summer cycle, the temperature in the pile of dried sludge remained above $20^{\circ} \mathrm{C}$ and its gradual increase during the experiment was recorded up to a value of above $28^{\circ} \mathrm{C}$. The air temperature inside the drying plant hall was changing and ranged from $18^{\circ} \mathrm{C}$ to $32^{\circ} \mathrm{C}$, with the average value of $25.2^{\circ} \mathrm{C}$. The mean difference between the inside temperature

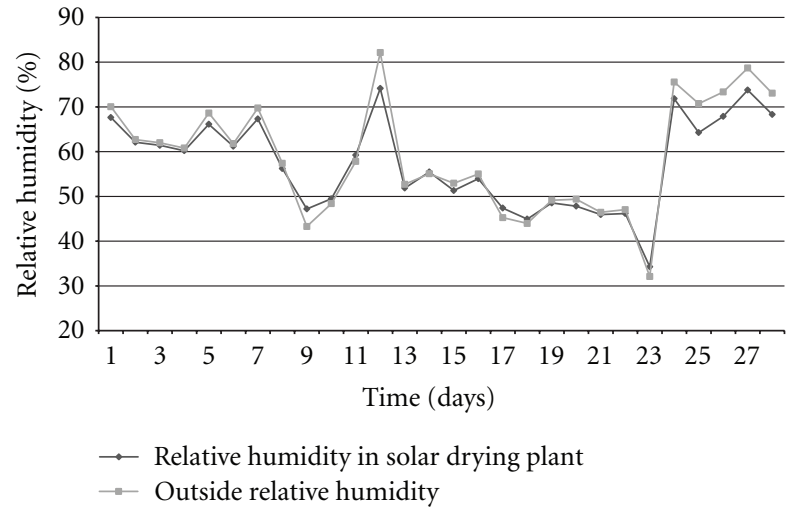

FIGURE 6: The course of relative humidity during the summer cycle (July).

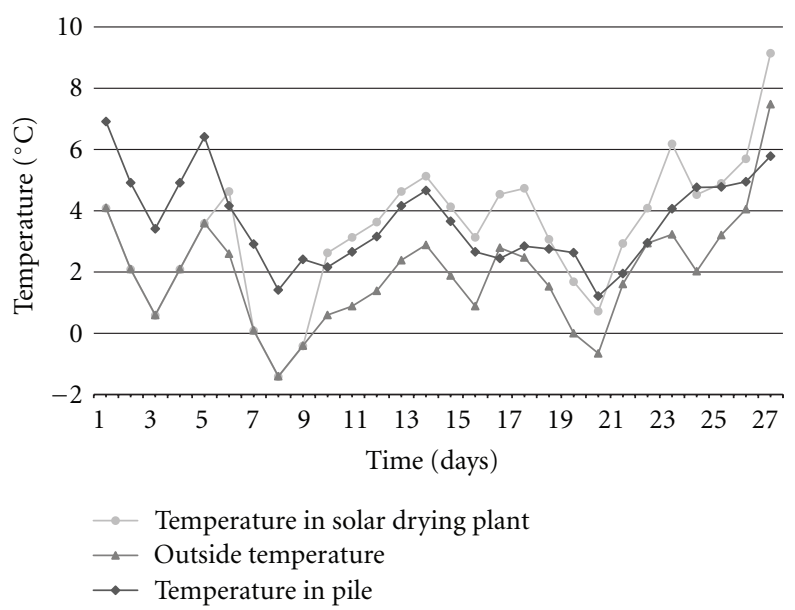

Figure 7: The course of temperature during the winter cycle (December).

in the drying plant and the outside temperature was on average $3.0^{\circ} \mathrm{C}$ (Figure 4 ).

The average daily level of solar radiation during the summer cycle was $327.8 \mathrm{~W} \times \mathrm{m}^{-2}$, and the maximal radiation recorded reached the value of $598.4 \mathrm{~W} \times \mathrm{m}^{-2}$ (Figure 5).

The course of the relative humidity inside the drying plant hall was dependent on the air humidity outside and in both cases it showed considerable fluctuations. The lowest observed value of relative humidity inside the hall was 34\%, whereas the highest was $74 \%$, on average $58 \%$ (Figure 6).

A detailed course of the analyzed indexes of microclimate in the winter cycle was presented in Figures 7, 8, and 9.

The temperatures recorded in the winter period were definitely lower. The average temperature in the pile remained at $3.6^{\circ} \mathrm{C}$, whereas the air temperature inside and outside the drying hall was $3.4^{\circ} \mathrm{C}$ and $2.0^{\circ} \mathrm{C}$, respectively, (Figure 7).

Also the solar radiation intensity reached considerably the lowest level in comparison with the summer cycle. The maximal value of radiation exceeded $72.0 \mathrm{~W} \times \mathrm{m}^{-2}$, whereas the minimal value did not fall below $6.3 \mathrm{~W} \times \mathrm{m}^{-2}$, giving an average of $27.7 \mathrm{~W} \times \mathrm{m}^{-2}$ (Figure 8 ). Thus the measured daily 


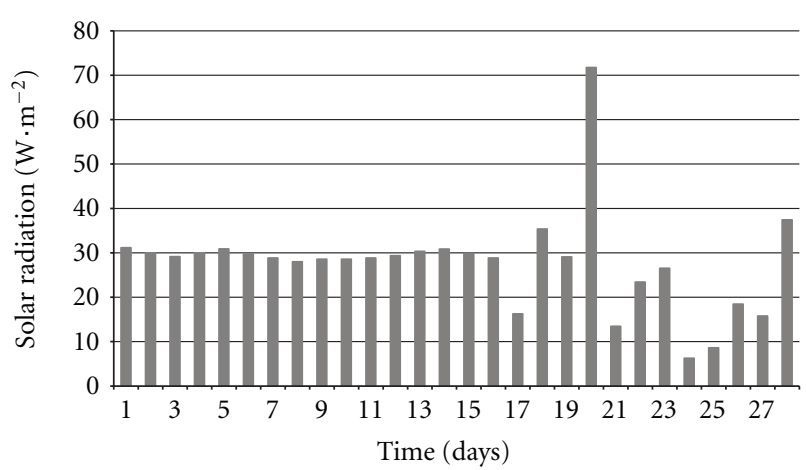

Figure 8: The course of insolation during the winter cycle (December).

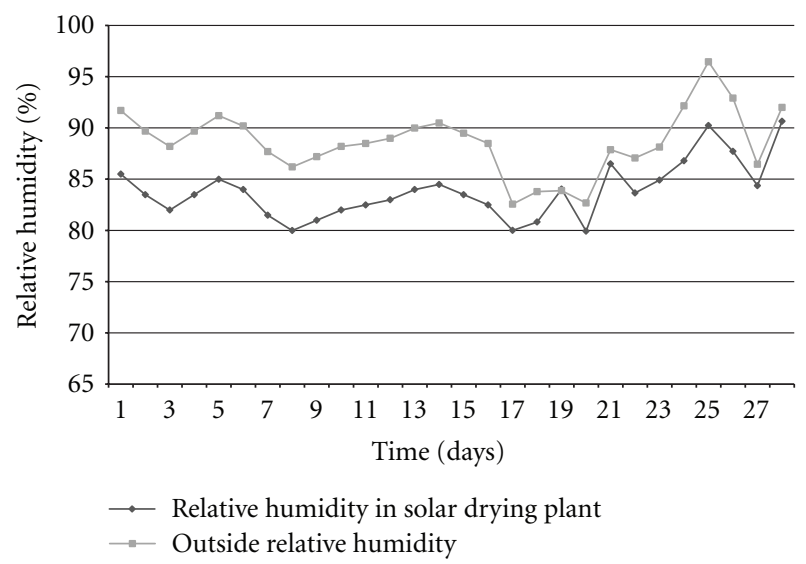

FIGURE 9: The course of relative humidity during the winter cycle (December).

intensity of solar radiation was insufficient for the effective drying by means of radiation [13].

The monitored air humidity in the winter cycle remained at the definitely higher level compared with the summer. Average values of the relative humidity inside the drying hall amounted to about $84 \%$, whereas outside this was $89 \%$ (Figure 9). Such a level of the air humidity made convective drying of sludge considerably more difficult [13].

The distribution of insolation and air temperature may vary in different regions of Poland. The total yearly solar radiation intensity in the studied location stays within the range 996-1022 $\mathrm{kWh} \times\left(\mathrm{m}^{2} \times \text { year }\right)^{-1}[14]$.

The average long-time relative humidity of the air in Poland expressed in percent during the year is $76 \%$, with the monthly average ranging from $71 \%$ in May to $88 \%$ in December. Large fluctuations occur in the daily cycle, irrespective of the season [15].

3.2. Physicochemical Analyses of Sewage Sludge. The average results of physicochemical analyses of sewage sludge in the summer cycle were presented in Table 2.

The dry matter of mechanically dewatered sludge processed in the drying plant reached the value $16.22 \%$. The $\mathrm{pH}$ value was close to neutral and amounted to $\mathrm{pH} 6.69$.
The content of organic substances in the sludge was $66.9 \%$ (Table 2).

The proportion of fertilizer components, phosphorus, calcium, and magnesium, was on the average level of the values for municipal sewage sludge, and the concentration of seven tested heavy metals was low, qualifying the sludge for use in agriculture (Table 2).

In the summer cycle, an increase in the sludge dry matter was clearly visible. On 7th day of the study, it grew on average to more than $40 \%$, and on 28th day of the cycle, sludge in the pile contained on average $86.4 \%$ dry matter. There was a decrease in organic substance proportion on 28th day of the study, as well as in total and ammonium nitrogen in dried sludge (Table 2). The other studied indexes were at the same level (Table 2).

Average results of physicochemical analyses of sewage sludge in the winter cycle were presented in Table 3.

Mechanically dewatered sludge processed in the drying plant in the winter cycle contained an average $13.86 \%$ dry matter, thus slightly less than in the summer period. The $\mathrm{pH}$ value had a marginally higher level than that in the summer cycle ( $\mathrm{pH}$ 6.90), but it was also close to neutral. The content of organic substances in the sludge was on average $64.2 \%$ and was slightly lower than in the summer cycle (Table 3 ).

Just as in the material intended for drying in the summer, the proportion of fertilizer components, phosphorus, calcium, and magnesium, was characteristic of municipal sewage sludge, and the content of seven studied heavy metals was low, qualifying sludge for use in agriculture (Table 3). It is worthy of note that the mercury content in sewage sludge subjected to solar drying in the winter cycle (Table 3 ) is much lower than in summer (Table 2). This difference probably results from a slightly different chemical composition of sewage (higher content of mercury) directed to the sewage treatment plant during the particular period, which directly influenced the physicochemical parameters of sewage sludge.

During the winter research cycle, a small increase in the sludge dry matter was visible, considerably smaller than in the summer. On 7th day of the study, it grew to more than $18.9 \%$. On 28th day of the study, the sludge in the pile contained 24.54\% D.M (Table 3).

Just as in the summer, also in the winter cycle a decrease in organic substance in the dried sludge from $64.2 \%$ to $62.4 \%$ was observed. Contrary to the summer period, a distinct decrease in the total nitrogen content during sludge drying did not occur. The other studied indexes were not changed (Table 3).

The humidity of raw material has a substantial effect on the final level of sewage sludge drying in the solar drying plant. In the present study, the average dry matter content in sludge after centrifuge was $16.22 \%$ in the summer cycle and $13.86 \%$ in the winter cycle (Tables 2 and 3 ) and did not differ significantly from that given by other authors [16-18], where it was in the range $13.80-28.00 \%$. In the summer cycle, the average proportion of dry matter in the sludge dried material after 28 days of the process increased to $86.4 \%$ and was similar to that observed by Bux et al. [16] during 21 days of solar drying. Slightly better effects of drying were reported 
TABLE 2: Average results of physicochemical analyses of sewage sludge in summer cycles.

\begin{tabular}{|c|c|c|c|c|c|c|}
\hline \multirow{3}{*}{ Parameter } & \multirow{3}{*}{ Unit } & \multicolumn{5}{|c|}{ Average results for summer cycles (replications number $=3$ ) } \\
\hline & & \multicolumn{5}{|c|}{ Sampling terms for the research (days) } \\
\hline & & 0 & 7 & 14 & 21 & 28 \\
\hline $\begin{array}{l}\text { Dry matter of sludge after } \\
\text { centrifuge }\end{array}$ & $\%$ & $16.22( \pm 0.16)^{*}$ & - & - & - & - \\
\hline Dry matter of sludge in the pile & $\%$ & - & $40.30( \pm 4.00)$ & $47.20( \pm 10.68)$ & $69.90( \pm 10.81)$ & $86.40( \pm 13.01)$ \\
\hline Organic substance & \% D.M. & $66.90( \pm 0.71)$ & $67.00( \pm 0.71)$ & $66.60( \pm 0.90)$ & $65.70( \pm 1.45)$ & $65.30( \pm 1.71)$ \\
\hline $\mathrm{pH}$ & - & $6.70( \pm 0.16)$ & $6.70( \pm 0.16)$ & $6.69( \pm 0.13)$ & $6.70( \pm 0.16)$ & $6.70( \pm 0.18)$ \\
\hline Total nitrogen content & \% D.M. & $4.08( \pm 1.27)$ & $4.05( \pm 1.28)$ & $3.60( \pm 1.19)$ & $3.30( \pm 1.04)$ & $3.20( \pm 1.04)$ \\
\hline Ammonium nitrogen content & \% D.M. & $0.19( \pm 0.09)$ & $0.16( \pm 0.10)$ & $0.17( \pm 0.06)$ & $0.15( \pm 0.02)$ & $0.15( \pm 0.02)$ \\
\hline Total phosphorus & \% D.M. & $2.14( \pm 0.99)$ & $2.12( \pm 0.98)$ & $2.12( \pm 0.98)$ & $2.05( \pm 0.94)$ & $2.12( \pm 0.98)$ \\
\hline Calcium content $(\mathrm{Ca})$ & \% D.M. & $1.13( \pm 0.14)$ & $1.12( \pm 0.15)$ & $1.12( \pm 0.15)$ & $1.13( \pm 0.14)$ & $1.13( \pm 0.14)$ \\
\hline Magnesium content $(\mathrm{Mg})$ & \% D.M. & $0.43( \pm 0.03)$ & $0.43( \pm 0.03)$ & $0.43( \pm 0.03)$ & $0.43( \pm 0.03)$ & $0.43( \pm 0.03)$ \\
\hline \multicolumn{7}{|l|}{ Heavy metals } \\
\hline Lead $(\mathrm{Pb})$ & mg/kg D.M. & $31.50( \pm 0.58)$ & $31.50( \pm 0.58)$ & $31.50( \pm 0.58)$ & $31.50( \pm 0.58)$ & $31.51( \pm 0.53)$ \\
\hline Cadmium (Cd) & mg/kg D.M. & $2.41( \pm 0.09)$ & $2.42( \pm 0.07)$ & $2.40( \pm 0.11)$ & $2.41( \pm 0.09)$ & $2.41( \pm 0.09)$ \\
\hline Mercury (Hg) & mg/kg D.M. & $1.03( \pm 0.60)$ & $1.00( \pm 0.57)$ & $1.00( \pm 0.57)$ & $1.00( \pm 0.57)$ & $1.00( \pm 0.57)$ \\
\hline Nickel (Ni) & mg/kg D.M. & $16.30( \pm 3.90)$ & $16.31( \pm 3.76)$ & $16.30( \pm 3.90)$ & $16.30( \pm 3.90)$ & $16.31( \pm 3.75)$ \\
\hline $\operatorname{Zinc}(\mathrm{Zn})$ & mg/kg D.M. & $1100.00( \pm 84.97)$ & $1100.00( \pm 84.97)$ & $1100.00( \pm 84.97)$ & $1100.00( \pm 84.97)$ & $1100.00( \pm 84.97)$ \\
\hline Copper $(\mathrm{Cu})$ & mg/kg D.M. & $240.50( \pm 19.05)$ & $240.50( \pm 19.05)$ & $240.52( \pm 20.17)$ & $240.51( \pm 20.15)$ & $240.50( \pm 19.05)$ \\
\hline Chromium (Cr) & mg/kg D.M. & $38.37( \pm 23.56)$ & $38.30( \pm 23.58)$ & $38.37( \pm 23.56)$ & $38.36( \pm 23.55)$ & $38.37( \pm 23.56)$ \\
\hline
\end{tabular}

${ }^{*}$ Standard deviation.

TABLE 3: Average results of physicochemical analyses of sewage sludge in winter cycles.

\begin{tabular}{|c|c|c|c|c|c|c|}
\hline \multirow{3}{*}{ Parameter } & \multirow{3}{*}{ Unit } & \multicolumn{5}{|c|}{ Average results for winter cycles (replications number $=3$ ) } \\
\hline & & \multicolumn{5}{|c|}{ Sampling terms for the research (days) } \\
\hline & & 0 & 7 & 14 & 21 & 28 \\
\hline Sludge dry matter after centrifuge & $\%$ & $13.86( \pm 0.62)^{*}$ & - & - & - & - \\
\hline Sludge dry matter in the pile & $\%$ & - & $18.90( \pm 3.21)$ & $21.43( \pm 4.33)$ & $25.12( \pm 3.93)$ & $24.54( \pm 4.84)$ \\
\hline Organic substance & \% D.M. & $64.20( \pm 2.17)$ & $65.50( \pm 2.04)$ & $64.20( \pm 2.65)$ & $63.40( \pm 2.87)$ & $62.40( \pm 3.50)$ \\
\hline $\mathrm{pH}$ & - & $6.90( \pm 0.06)$ & $6.90( \pm 0.06)$ & $7.00( \pm 0.11)$ & $6.98( \pm 0.10)$ & $6.90( \pm 0.06)$ \\
\hline Total nitrogen content & \% D.M. & $2.10( \pm 0.15)$ & $2.12( \pm 0.17)$ & $2.00( \pm 0.06)$ & $2.12( \pm 0.17)$ & $2.09( \pm 0.23)$ \\
\hline Ammonium nitrogen content & \% D.M. & $0.10( \pm 0.06)$ & $0.10( \pm 0.06)$ & $0.11( \pm 0.04)$ & $0.09( \pm 0.03)$ & $0.15( \pm 0.01)$ \\
\hline Total phosphorus & \% D.M. & $2.20( \pm 0.12)$ & $2.22( \pm 0.13)$ & $2.21( \pm 0.11)$ & $2.20( \pm 0.12)$ & $2.20( \pm 0.12)$ \\
\hline Calcium content $(\mathrm{Ca})$ & \% D.M. & $1.15( \pm 0.03)$ & $1.13( \pm 0.03)$ & $1.12( \pm 0.02)$ & $1.15( \pm 0.03)$ & $1.15( \pm 0.03)$ \\
\hline Magnesium content (Mg) & \% D.M. & $0.23( \pm 0.04)$ & $0.23( \pm 0.04)$ & $0.23( \pm 0.04)$ & $0.34( \pm 0.05)$ & $0.23( \pm 0.03)$ \\
\hline \multicolumn{7}{|l|}{ Heavy metals } \\
\hline Lead $(\mathrm{Pb})$ & mg/kg D.M. & $22.23( \pm 2.79)$ & $22.20( \pm 2.76)$ & $22.20( \pm 2.76)$ & $22.20( \pm 2.76)$ & $22.20( \pm 2.76)$ \\
\hline Cadmium (Cd) & mg/kg D.M. & $1.98( \pm 0.26)$ & $1.97( \pm 0.21)$ & $1.89( \pm 0.20)$ & $1.89( \pm 0.20)$ & $1.87( \pm 0.18)$ \\
\hline Mercury (Hg) & mg/kg D.M. & $0.05( \pm 0.03)$ & $0.05( \pm 0.03)$ & $0.05( \pm 0.03)$ & $0.00(-)$ & $0.05( \pm 0.03)$ \\
\hline Nickel (Ni) & mg/kg D.M. & $19.50( \pm 1.94)$ & $19.50( \pm 2.12)$ & $19.50( \pm 1.94)$ & $19.50( \pm 1.94)$ & $19.50( \pm 1.94)$ \\
\hline Zinc $(\mathrm{Zn})$ & mg/kg D.M. & $\begin{array}{c}1248.00 \\
( \pm 131.15)\end{array}$ & $\begin{array}{c}1248.00 \\
( \pm 131.15)\end{array}$ & $\begin{array}{c}1248.00 \\
( \pm 131.15)\end{array}$ & $\begin{array}{c}1249.00 \\
( \pm 125.87)\end{array}$ & $\begin{array}{c}1250.00 \\
( \pm 126.26)\end{array}$ \\
\hline Copper $(\mathrm{Cu})$ & mg/kg D.M. & $220.70( \pm 17.43)$ & $220.70( \pm 17.43)$ & $220.70( \pm 17.43)$ & $220.70( \pm 17.50)$ & $220.70( \pm 17.43)$ \\
\hline Chromium (Cr) & mg/kg D.M. & $27.64( \pm 2.08)$ & $27.64( \pm 2.08)$ & $27.64( \pm 2.08)$ & $27.64( \pm 2.08)$ & $27.64( \pm 2.08)$ \\
\hline
\end{tabular}

${ }^{*}$ Standard deviation. 
TABLE 4: Number of indicator bacteria in particular determination times.

\begin{tabular}{|c|c|c|c|c|c|c|}
\hline \multirow[t]{2}{*}{ Cycle } & \multirow[t]{2}{*}{ Bacteria number $\left[\mathrm{MPN} \times \mathrm{g}^{-1}\right]$} & \multicolumn{5}{|c|}{$\begin{array}{l}\text { Drying time } \\
\text { (days) }\end{array}$} \\
\hline & & 0 & 7 & 14 & 21 & 28 \\
\hline \multicolumn{7}{|c|}{ Sludge from carriers placed on the turner frame } \\
\hline \multirow{3}{*}{ Summer } & Salmonella Senftenberg $\mathrm{W}_{775}$ & $4.5 \times 10^{7}$ & $3.83 \times 10^{6}$ & $9.97 \times 10^{7}$ & $4.83 \times 10^{5}$ & $2.8 \times 10^{5}$ \\
\hline & Escherichia coli & $4.33 \times 10^{7}$ & $6.83 \times 10^{6}$ & $3.17 \times 10^{4}$ & $6.83 \times 10^{3}$ & $4.5 \times 10^{3}$ \\
\hline & Enterococci & $6.13 \times 10^{7}$ & $5.5 \times 10^{6}$ & $4.15 \times 10^{7}$ & $2.13 \times 10^{5}$ & $1.87 \times 10^{5}$ \\
\hline \multirow{3}{*}{ Winter } & Salmonella Senftenberg $\mathrm{W}_{775}$ & $2.13 \times 10^{9}$ & $3.83 \times 10^{8}$ & $1.38 \times 10^{9}$ & $1.73 \times 10^{7}$ & $3.83 \times 10^{6}$ \\
\hline & Escherichia coli & $3.83 \times 10^{7}$ & $3.83 \times 10^{7}$ & $1.51 \times 10^{8}$ & $6.17 \times 10^{4}$ & $1.83 \times 10^{5}$ \\
\hline & Enterococci & $9.0 \times 10^{7}$ & $1.82 \times 10^{9}$ & $1.25 \times 10^{9}$ & $1.07 \times 10^{9}$ & $3.25 \times 10^{8}$ \\
\hline \multicolumn{7}{|c|}{ Sludge from carriers placed on the turner shovels } \\
\hline \multirow{3}{*}{ Summer } & Salmonella Senftenberg $\mathrm{W}_{775}$ & $4.5 \times 10^{7}$ & $6.5 \times 10^{6}$ & $2.86 \times 10^{5}$ & $4.9 \times 10^{3}$ & $4.67 \times 10^{2}$ \\
\hline & Escherichia coli & $4.33 \times 10^{7}$ & $4.33 \times 10^{5}$ & $7.83 \times 10^{6}$ & $2.65 \times 10^{4}$ & $7.65 \times 10^{3}$ \\
\hline & Enterococci & $6.13 \times 10^{7}$ & $2.15 \times 10^{8}$ & $4.37 \times 10^{8}$ & $5.17 \times 10^{6}$ & $5.5 \times 10^{6}$ \\
\hline \multirow{3}{*}{ Winter } & Salmonella Senftenberg $\mathrm{W}_{775}$ & $2.13 \times 10^{9}$ & $1.38 \times 10^{9}$ & $1.73 \times 10^{8}$ & $2.83 \times 10^{6}$ & $1.72 \times 10^{7}$ \\
\hline & Escherichia coli & $3.83 \times 10^{7}$ & $7.17 \times 10^{7}$ & $9.67 \times 10^{5}$ & $9.33 \times 10^{4}$ & $1.55 \times 10^{5}$ \\
\hline & Enterococci & $9.0 \times 10^{7}$ & $6.17 \times 10^{8}$ & $2.38 \times 10^{8}$ & $3.17 \times 10^{8}$ & $1.07 \times 10^{9}$ \\
\hline \multicolumn{7}{|c|}{ Sudge from carriers placed in the sludge pile } \\
\hline \multirow{3}{*}{ Summer } & Salmonella Senftenberg $\mathrm{W}_{775}$ & $4.5 \times 10^{7}$ & $3.17 \times 10^{6}$ & $1.77 \times 10^{6}$ & $6.17 \times 10^{5}$ & $3.17 \times 10^{5}$ \\
\hline & Escherichia coli & $4.33 \times 10^{7}$ & $2.84 \times 10^{7}$ & $3.8 \times 10^{5}$ & $3.26 \times 10^{4}$ & $7.17 \times 10^{2}$ \\
\hline & Enterococci & $6.13 \times 10^{7}$ & $3.75 \times 10^{8}$ & $2.48 \times 10^{7}$ & $5.98 \times 10^{4}$ & $7.17 \times 10^{3}$ \\
\hline \multirow{3}{*}{ Winter } & Salmonella Senftenberg $\mathrm{W}_{775}$ & $2.13 \times 10^{9}$ & $2.13 \times 10^{9}$ & $5.58 \times 10^{8}$ & $7.83 \times 10^{6}$ & $6.83 \times 10^{6}$ \\
\hline & Escherichia coli & $3.83 \times 10^{7}$ & $2.5 \times 10^{7}$ & $7.83 \times 10^{5}$ & $1.2 \times 10^{6}$ & $3.17 \times 10^{6}$ \\
\hline & Enterococci & $9.0 \times 10^{7}$ & $9.17 \times 10^{8}$ & $1.67 \times 10^{8}$ & $1.13 \times 10^{9}$ & $1.67 \times 10^{9}$ \\
\hline
\end{tabular}

by Hertwig [19], as after 20 days of the process sewage sludge contained $94 \%$ dry matter.

3.3. Microbiological Analyses. In the sludge after centrifuging collected to the analyses, no bacilli of the genus Salmonella were isolated, and the number of isolated E. coli and enterococci was on average $10^{5}$ and $10^{4} \mathrm{NPL} \times \mathrm{g}^{-1}$, respectively.

Using the PCR technique, it was found that the bacteria reisolated from carriers and cultured on BPLS agar belonged to the genus Salmonella. Their presence was proved by the product of $284 \mathrm{bp}$ corresponding to the fragment invA (Figure 10).

The results of API 20E tests for the microorganisms grown on ENDO agar determined the code 5144572, typical of $E$. coli. The final identification of bacteria grown on agar with kanamycin and azide based on the Phadebact D-Strep Test confirmed the presence of enterococci.

During sewage sludge solar drying in the summer cycle, a partial elimination of all the studied bacteria was observed (Table 4). This was dependent on the kind of carriers and their location. The population of Salmonella Senftenberg $\mathrm{W}_{775}$ decreased during 28 days of the process on average by about 2 log in sludge from the carriers placed on the frame of the turner and from carriers placed in the pile (Table 4).

In the carriers placed on the shovels of the turner, a reduction in their population was on average as much as

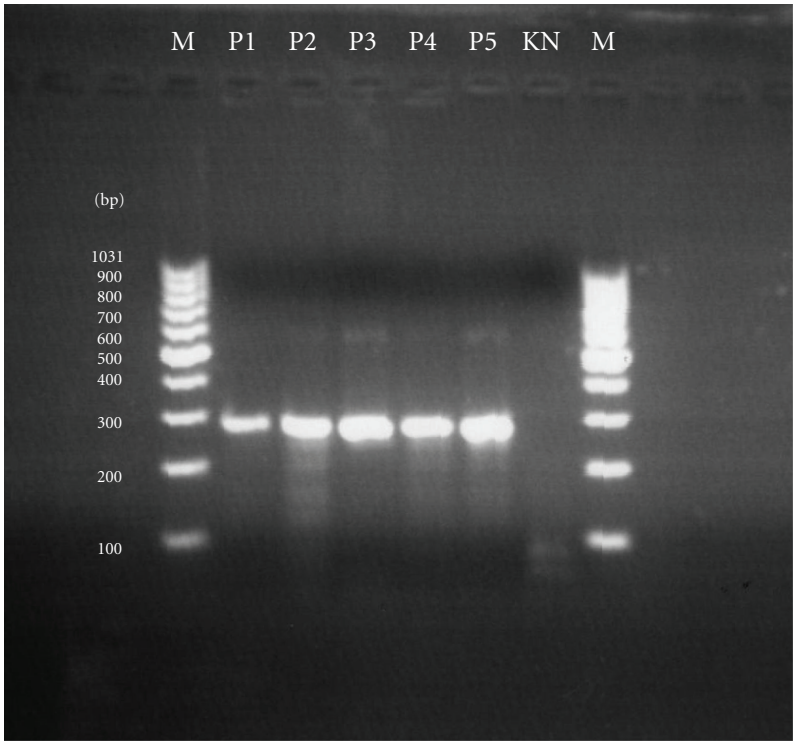

FIgure 10: The PCR test confirming the presence of bacilli in the studied material (M: the size marker, P1: a sample from the carrier placed on the frame of the turner, P2: a sample from the carrier placed on the shovels of the turner; P3: a sample from the carrier placed in the sludge pile, P4: Salmonella Agona, P5: Salmonella Braenderup H9812 (P4 and P5: positive control), KN: negative control). 
TABLE 5: Results of statistical analysis of obtained microbiological data.

\begin{tabular}{|c|c|c|c|c|c|}
\hline Cycle & Bacteria & Regression equation & $R^{2}(\%)$ & $\begin{array}{c}\text { Theoretical time of } \\
\text { survival (days) }\end{array}$ & $\begin{array}{c}\text { Elimination rate }(\log \\
\left.\mathrm{MPN} \times \mathrm{day}^{-1}\right)\end{array}$ \\
\hline \multicolumn{6}{|c|}{ Sludge from carriers placed on the turner frame } \\
\hline \multirow{3}{*}{ Summer } & $\begin{array}{l}\text { Salmonella } \\
\text { Senftenberg W775 }\end{array}$ & $y=-0.075 x+7.57$ & 61.11 & $104 \mathrm{~A}, \mathrm{a}, \mathrm{c}, \mathrm{j}$ & 0.08A,G,a,e,f,j,n \\
\hline & Escherichia coli & $y=-0.157 x+7.43$ & 88.93 & $47^{\mathrm{B}, \mathrm{a}, \mathrm{c}, \mathrm{j}}$ & $0.16^{\mathrm{B}, \mathrm{D}, \mathrm{a}, \mathrm{d}, \mathrm{j}, \mathrm{n}}$ \\
\hline & Enterococci & $y=-0.089 x+7.68$ & 68.95 & $89^{\mathrm{A}, \mathrm{D}, \mathrm{a}, \mathrm{d}, \mathrm{j}}$ & $0.09^{\mathrm{A}, \mathrm{D}, \mathrm{G}, \mathrm{c}, \mathrm{e}, \mathrm{f}, \mathrm{g}}$ \\
\hline \multirow{3}{*}{ Winter } & $\begin{array}{l}\text { Salmonella } \\
\text { Senftenberg } \mathrm{W}_{775}\end{array}$ & $y=-0.103 x+9.48$ & 77.69 & $94^{\mathrm{A}, \mathrm{E}, \mathrm{a}, \mathrm{e}, \mathrm{j}, \mathrm{g}}$ & $0.10^{\mathrm{A}, \mathrm{D}, \mathrm{G}, \mathrm{I}, \mathrm{b}, \mathrm{e}, \mathrm{h}}$ \\
\hline & Escherichia coli & $y=-0.106 x+7.85$ & 65.97 & $75^{\mathrm{A}, \mathrm{B}, \mathrm{b}, \mathrm{d}, \mathrm{f}, \mathrm{g}}$ & $0.11^{\mathrm{A}, \mathrm{D}, \mathrm{G}, \mathrm{I}, \mathrm{b}, \mathrm{e}, \mathrm{h}}$ \\
\hline & Enterococci & $y=0.012 x+8.46$ & 6.26 & - & $0.01^{\mathrm{C}, \mathrm{E}, \mathrm{a}, \mathrm{e}, \mathrm{i}, \mathrm{m}}$ \\
\hline \multicolumn{6}{|c|}{ Sludge from carriers placed on turner shovels } \\
\hline \multirow{3}{*}{ Summer } & $\begin{array}{l}\text { Salmonella } \\
\text { Senftenberg } \mathrm{W}_{775}\end{array}$ & $y=-0.192 x+7.72$ & 96.57 & $40^{\mathrm{B}, \mathrm{a}, \mathrm{c}, \mathrm{j}}$ & $0.19^{\mathrm{B}, \mathrm{F}, \mathrm{a}, \mathrm{e}, \mathrm{j}, \mathrm{n}}$ \\
\hline & Escherichia coli & $y=-0.139 x+7.51$ & 74.77 & $55^{\mathrm{B}, \mathrm{D}, \mathrm{E}, \mathrm{c}, \mathrm{h}, \mathrm{k}}$ & $0.14^{\mathrm{A}, \mathrm{D}, \mathrm{F}, \mathrm{H}, \mathrm{I}, \mathrm{b}, \mathrm{d}, \mathrm{i}, \mathrm{k}, \mathrm{l}}$ \\
\hline & Enterococci & $y=-0.050 x+8.23$ & 38.99 & $168^{\mathrm{C}, \mathrm{F}, \mathrm{G}, \mathrm{a}, \mathrm{c}, \mathrm{f}, \mathrm{h}}$ & $0.05^{\mathrm{E}, \mathrm{G}, \mathrm{f}, \mathrm{j}, \mathrm{k}}$ \\
\hline \multirow{3}{*}{ Winter } & $\begin{array}{l}\text { Salmonella } \\
\text { Senftenberg } \mathrm{W}_{775}\end{array}$ & $y=-0.096 x+9.29$ & 70.46 & $98^{\mathrm{A}, \mathrm{a}, \mathrm{c}, \mathrm{j}}$ & $0.10^{\mathrm{A}, \mathrm{D}, \mathrm{G}, \mathrm{I}, \mathrm{e}, \mathrm{l}, \mathrm{m}}$ \\
\hline & Escherichia coli & $y=-0.111 x+7.78$ & 77.03 & $71^{\mathrm{A}, \mathrm{B}, \mathrm{E}, \mathrm{b}, \mathrm{d}, \mathrm{h}, \mathrm{l}, \mathrm{k}}$ & $0.11^{\mathrm{A}, \mathrm{D}, \mathrm{G}, \mathrm{I}, \mathrm{c}, \mathrm{e}, \mathrm{l}, \mathrm{o}}$ \\
\hline & Enterococci & $y=0.030 x+8.01$ & 36.67 & - & $-0.03^{\mathrm{C}, \mathrm{a}, \mathrm{e}, \mathrm{j}, \mathrm{l}, \mathrm{n}}$ \\
\hline \multicolumn{6}{|c|}{ Sludge from carriers placed in a sludge pile } \\
\hline \multirow{3}{*}{ Summer } & $\begin{array}{l}\text { Salmonella } \\
\text { Senftenberg } \mathrm{W}_{775}\end{array}$ & $y=-0.070 x+7.28$ & 91.29 & $104^{\mathrm{A}, \mathrm{a}, \mathrm{c}, \mathrm{j}}$ & $0.07^{\mathrm{A}, \mathrm{G}, \mathrm{a}, \mathrm{e}, \mathrm{j}, \mathrm{n}}$ \\
\hline & Escherichia coli & $y=-0.187 x+7.84$ & 92.09 & $42^{\mathrm{B}, \mathrm{a}, \mathrm{c}, \mathrm{j}}$ & $0.19^{\mathrm{B}, \mathrm{H}, \mathrm{a}, \mathrm{e}, \mathrm{j}, \mathrm{n}}$ \\
\hline & Enterococci & $y=-0.165 x+8.57$ & 79.27 & $52^{\mathrm{B}, \mathrm{D}, \mathrm{c}, \mathrm{e}, \mathrm{k}}$ & $0.17^{\mathrm{B}, \mathrm{I}, \mathrm{a}, \mathrm{g}, \mathrm{k}, \mathrm{n}}$ \\
\hline \multirow{3}{*}{ Winter } & $\begin{array}{l}\text { Salmonella } \\
\text { Senftenberg } \mathrm{W}_{775}\end{array}$ & $y=-0.107 x+9.60$ & 81.05 & $90^{\mathrm{A}, \mathrm{D}, \mathrm{a}, \mathrm{f}, \mathrm{i}, \mathrm{j}, \mathrm{k}, \mathrm{k}}$ & $0.11^{\mathrm{A}, \mathrm{D}, \mathrm{G}, \mathrm{I}, \mathrm{c}, \mathrm{e}, \mathrm{l}, \mathrm{p}}$ \\
\hline & Escherichia coli & $y=0.051 x+7.37$ & 50.05 & $148^{\mathrm{C}, \mathrm{F}, \mathrm{G}, \mathrm{g}, \mathrm{j}, \mathrm{k}}$ & $0.05^{\mathrm{E}, \mathrm{G}, \mathrm{g}, \mathrm{k}, \mathrm{n}}$ \\
\hline & Enterococci & $y=0.035 x+7.99$ & 40.77 & - & $0.04^{\mathrm{C}, \mathrm{a}, \mathrm{g}, \mathrm{h}, \mathrm{j}, \mathrm{k}, \mathrm{o}, \mathrm{p}, \mathrm{m}}$ \\
\hline
\end{tabular}

A, B, C, ... Highly statistically significant differences $(P \leq 0.01)$.

a, b, c,... Statistically significant differences $(P \leq 0.05)$.

$5 \log$. The mean theoretical time of survival of Salmonella Sanftenberg $\mathrm{W}_{775}$ in the summer cycle, calculated based on the regression equations, was 104 days in dried sludge from the carriers placed on the frame of the turner and in the pile. This time was highly statistically significantly longer than that in the sludge from carriers on the shovels of the turner (40 days) (Table 5). The elimination rate of the bacteria on the shovels was highly significantly higher $\left(0.19 \log\right.$ MPN $\left.\times \mathrm{day}^{-1}\right)$ in relation to the other samples $\left(0.08\right.$ and $0.07 \log$ MPN $\times$ day $\left.^{-1}\right)($ Table 5).

At the same time, the number of $E$. coli isolated from carriers located on the frame and shovels of the turner decreased on average by about $4 \log$, whereas in the pile by about $5 \log$ (Table 4). The mean theoretical times of survival ranged from 42 to 55 days (Table 5).

In the summer cycle, the highest average decrease in the number of enterococci, amounting to $4 \mathrm{log}$, was observed in the sludge from carriers placed in the pile, whereas the lowest, about $1 \mathrm{log}$, was observed in the material from carriers on the turner shovels (Table 4). In the sludge subjected to solar drying in the summer cycle, enterococci were theoretically able to survive on average from 52 days in the material from carriers placed in the pile to 168 days in samples from the turner shovels, at the elimination rate ranging from 0.05 to $0.17 \log$ MPN $\times$ day $^{-1}$ (Table 5). Highly statistically significant differences in the theoretical survival rates of enterococci were found between the material from the pile and the sludge from the other two locations, and statistically significant differences between samples from the turner frame and those from the pile (Table 5).

The available literature data shows that solar drying does not provide the complete sanitization of sewage sludge even in the summer cycles. The study by Bux et al. [16] conducted on technical scale in sludge solar drying plants working with charging method indicated that during the cycle lasting 21 days a reduction in the number of fecal coliform bacteria by $3 \log _{10}$ was obtained. Also in experiments conducted in Australia [20], despite more favorable climatic conditions, a considerable smaller decrease in the number of $E$. coli was found in comparison with the present study, amounting to $1 \log _{10}$. Also in the pilot study conducted in Turkey by Ögleni and Özdemir [21], the number of fecal coliform bacteria in sludge after 12 weeks of solar drying did not fall below $1.0 \times 10^{3} \mathrm{MPN} \times \mathrm{g}^{-1}$ D.M., just as during its 
storage. Mathioudakis et al. [22], in spite of very high temperatures, from 35 to $40^{\circ} \mathrm{C}$, and large sun exposure from 950 to $1000 \mathrm{~W} \times \mathrm{m}^{-2}$, obtained only a slight reduction in the number of coliform bacteria from $4 \times 10^{6}$ to $2 \times$ $10^{4} \mathrm{MPN} \times \mathrm{g}^{--}$D.M. and of fecal coliform bacteria from 3 $\times 10^{5}$ to $10^{3} \mathrm{MPN} \times \mathrm{g}^{-1}$ D.M. in the dried sludge. Different results were obtained by Cota et al. [17] studying sludge at the pilot sludge drying plant in Mexico. The elimination of the studied pathogens proceeded in a very fast rate there. At the beginning of the research cycle, the number of fecal coliform bacteria amounted to $3.87 \times 10^{6} \mathrm{MPN} \times \mathrm{g}^{-1} \mathrm{D} . \mathrm{M}$. After 4 days ( $98 \mathrm{~h}$ ), a decrease in the number up to $7.74 \times$ $10^{4} \mathrm{MPN} \times \mathrm{g}^{-1}$ D.M. was obtained, whereas after 11 days $(269 \mathrm{~h})$ only up to $1.6 \times 10^{0} \mathrm{MPN} \times \mathrm{g}^{-1}$ D.M. were isolated.

During the winter cycle of sludge solar drying, the number of Salmonella Senftenberg $\mathrm{W}_{775}$ decreased on average by $2-3 \log$, depending on the location (Table 4 ). The average theoretical time of survival calculated based on the regression line equation ranged from 90 to 98 days, at the elimination rate from 0.11 to $0.10 \log \mathrm{MPN} \times \mathrm{day}^{-1}$, respectively (Table 5 ). The above values did not differ significantly (Table 5). In the sludge from carriers located on the turner frame and in the pile, bacilli of Salmonella Senftenberg $\mathrm{W}_{775}$ theoretically survived slightly shorter in the winter cycle as compared with the summer, whereas in the samples from the turner shovels the reverse tendency occurred, and the differences in the survival time and elimination rate were highly statistically significant (Table 5).

A decrease in the number of $E$. coli in the winter period was very low and ranged between 1 and $2 \log$ (Table 4). The average theoretical time of survival of $E$. coli in the winter cycle ranged from 75 to 148 days at the elimination rate within the range $0.05-0.11 \log$ MPN $\times$ day $^{-1}$ (Table 5). Differences in the theoretical survival time between microorganisms isolated from the carriers placed in the pile and those obtained from samples collected at the other two locations were highly statistically significant, and those in the elimination rate were statistically significant (Table 5). Bacilli of $E$. coli survived longer in the winter cycle than in summer, and the observed differences in the theoretical survivability and elimination rate resulting from the season were highly statistically significant for the microorganisms isolated from the carriers placed in the pile and statistically significant for the bacilli from the carriers located on the frame of the turner (Table 5).

A low effectiveness of the method of sewage sludge solar drying in the winter cycle is particularly noticeable on the example of the dynamics of changes in enterococci population count. Conditions prevailing in the drying plant during winter did not cause the elimination of those bacteria, but contributed to their unexpected multiplication. During 28 days of the process, the count of enterococci in sludge from the carriers placed on the turner frame increased on average by about $1 \mathrm{log}$, whereas at the other two locations the increase was at a level of $2 \log$ (Table 4 ).

A very low sanitization effectiveness of drying process in the winter cycle observed in the present study confirms the results obtained by Mathioudakis et al. [22], who did not report a significant reduction in the microorganism
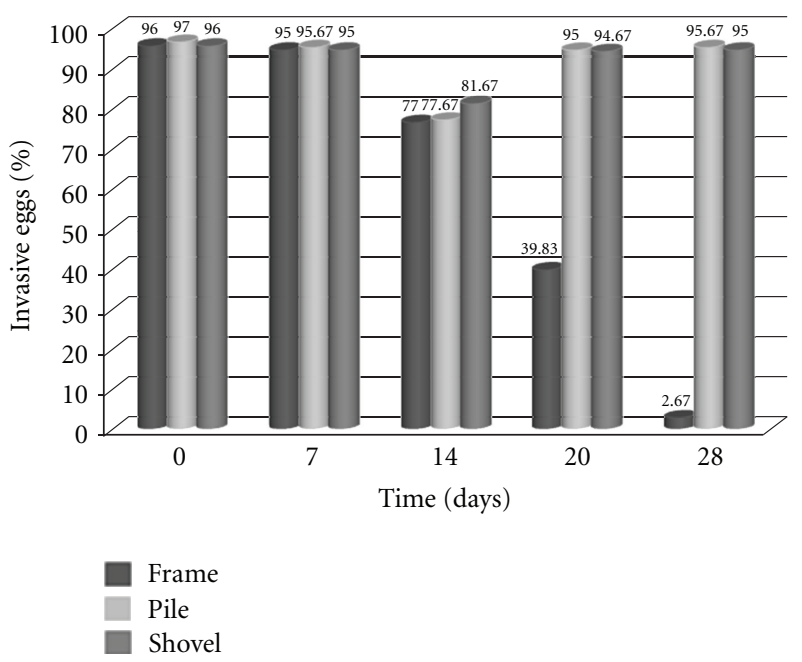

Figure 11: The course of inactivation of Ascaris suum eggs in summer cycle (July).

quantity in winter. The amount of E. coli they found in dried wastes was high and ranged from $8 \times 10^{5}$ to $2 \times$ $10^{6} \mathrm{MPN} \times \mathrm{g}^{-1}$ D.M. Also Ögleni and Özdamir [21] under autumn and winter conditions obtained a low degree of elimination of faecal coliforms, not exceeding $1 \log _{10}$. Bux et al. [16] obtained different results. The authors observed a reduction in faecal coliforms from $2.4 \times 10^{5}$ to $9.3 \times$ $10^{1} \mathrm{MPN} \times \mathrm{g}^{-1}$ D.M. after 49 days.

3.4. Parasitological Analyses. The results of the study obtained in the summer cycle indicated that waste solar drying resulted in a small inactivation of parasite eggs (Figure 11). However, during the experiment, clear fluctuations in the percentage of invasive eggs in individual carriers could be observed (Figure 11), which may indicate the lack of uniform conditions during the drying process and its poor sanitization potential.

The environmental impact on retaining invasiveness by Ascaris suum eggs was largely dependent on location of the carriers. After 28 days of the process, on average 93.33\% decrease in live parasite eggs was obtained in the carrier located on the frame (Figure 11). However, a slight reduction, that is, from $1.0 \%$ to $1.33 \%$, was obtained in the research material placed on the shovel of the turner and in the waste pile (Figure 11). Such considerable reduction in the percentage of invasive eggs in the carrier on the frame may result from the fact that material placed inside had the smallest contact with the mass of dried sludge. Therefore it was more susceptible to drying and the effect of higher temperature, that is, factors facilitating the elimination of Ascaris suum eggs, which are very sensitive to moisture deficit.

During the winter cycle, similarly to the summer period, slight fluctuations in the percentage of Ascaris suum eggs were observed in the material collected from the carriers, which indicated the lack of proper waste sanitization (Figure 12). In the winter cycle a considerable decrease in 
TABLE 6: Values of parameters that determine the way of using sewage sludge [11].

Type of reuse

Number Parameter

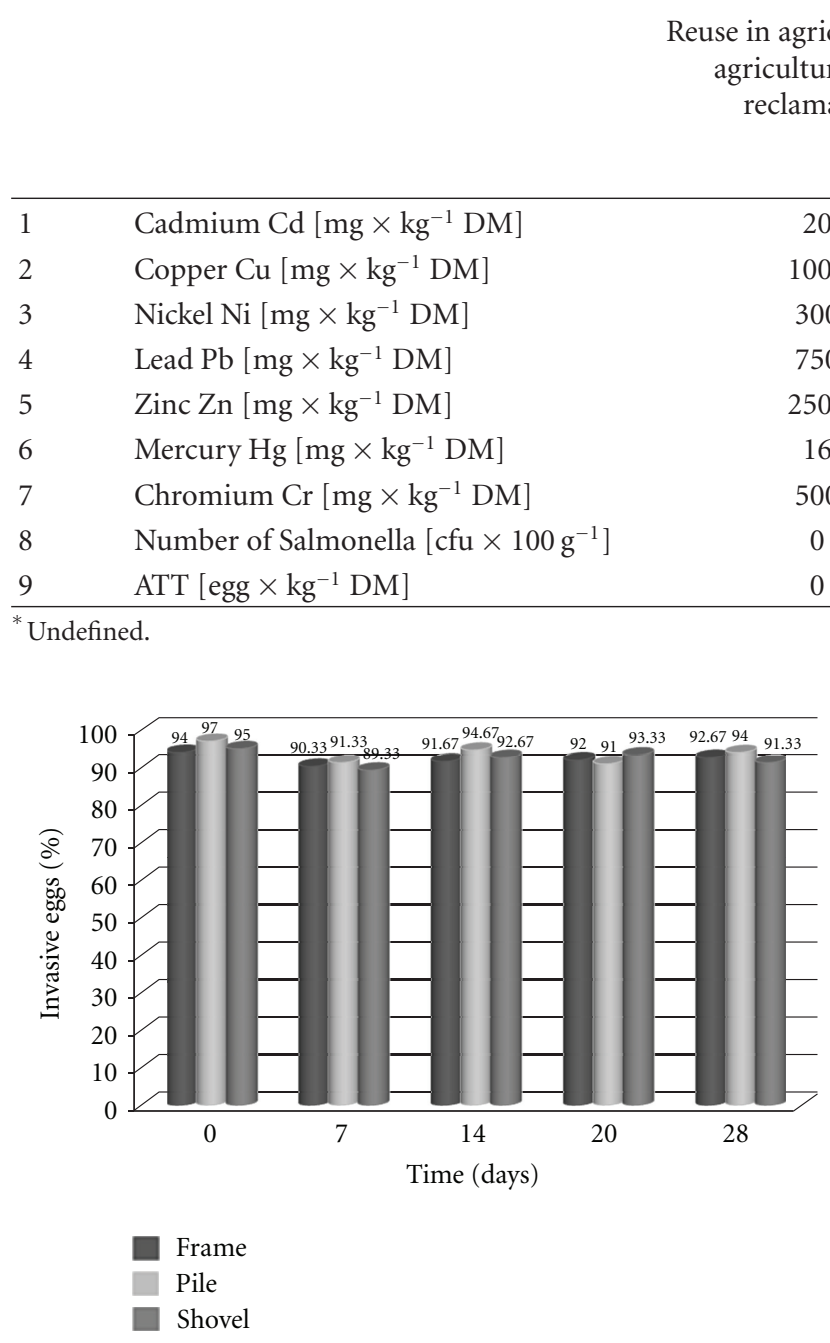

FIgURE 12: The course of inactivation of Ascaris suum eggs in winter cycle (December).

percentage of invasive $A$. suum eggs in the carrier on the frame was not observed, since temperature inside the hall was lower and air humidity was higher than in the summer season.

Different results were obtained by Shanahan et al. [23] who, while conducting a study of a system with an aisle turner in south-east Queensland, observed a reduction in the number of invasive eggs of Ascaris sp. and Taenia sp. during waste solar drying to the level below 1 egg per $4 \mathrm{~g}$ of dry matter.

Hertwig [19] proves that the main factor limiting a development of helminth eggs in wastes is a decrease in water activity index $\left(a_{w}\right)$ below 0.65 . Obtaining an increase in dry matter to $94 \%$ after 20 days of intensive waste drying, he observed the complete elimination of Ascaris suum eggs.
A similar phenomenon was observed by Cota et al. [17] who proved that an increase in the proportion of waste dry matter during solar drying up to $93.33 \%$ resulted in the effective inactivation of the eggs of Ascaris lumbricoides and Hymenolepis.

The obtained results of microbiological and parasitological analyses show that the process of sewage sludge solar drying does not provide sufficient hygienization, and in some cases it favors multiplying microorganisms in dried material. Therefore it is essential to show possibilities for management of the final product generated in described facility. The basic Polish legal act laying down guidelines of sewage sludge management depending on its properties is the Regulation of the Minister of Environment of 13 July 2010 on municipal sewage sludge (Dz.U. of 2010 no. 137 item 924) [11]. This regulation is in accordance with international regulations, including the following:

(i) Regulation (EC) no. 1774/2002 of the European Parliament and of the Council of 3 October 2002 laying down health rules concerning animal by-products not intended for human consumption,

(ii) Directive 98/34/EC of the European Parliament and of the Council of 22 June 1998 laying down a procedure for the provision of information in the field of technical standards,

(iii) and Council Directive 86/278/EEC of 12 June 1986 on the protection of the environment, and in particular of the soil, when sewage sludge is used in agriculture.

The above mentioned regulation [11] includes values of parameters determining the way of sewage sludge management (Table 6). It is notable that in most cases sludge subjected to drying is relatively safe in microbiological and parasitological terms and contain normative amount of heavy metals. Consequently, the product obtained after solar 
drying can be used as a fertilizer. However, in the case of occurrence of pathogenic bacteria and eggs of gastrointestinal parasites in the batch material, as it was in the described experiment, the hygienization potential of solar drying plant is insufficient. In such situation, sludge after drying can be used for nonagricultural land reclamation, cultivation of plants destined for compost production and cultivation of plants which are not destined for consumption and fodder production, or constitute an energy substrate in the process of burning or coburning.

During the operation of sludge solar drying plant, constant microbiological and parasitological monitoring of both watered and dried sludge making its final product is of utmost importance. Only obtaining such results, it is possible to choose the optimal way of managing processed sludge.

\section{Conclusions}

Based on the obtained results, it may be concluded that waste solar drying is a technology that does not guarantee obtaining of stable, biologically safe material for agricultural purposes. The lack of explicit positive results of elimination of harmful microflora in both seasons of the year in drying plants located under various climatic conditions confirms that solar drying technology cannot be regarded as an effective technology of waste sanitization. In this respect, it is much less effective than other biological (e.g., composing), chemical (e.g., liming), and physical (e.g., pasteurization) methods of waste processing. To obtain sanitary clean wastes, the vast majority of the authors report the need for additional sanitization treatments. Subjecting waste dried material to pelletization may guarantee obtaining its proper sanitization.

\section{References}

[1] J. A. Oleszkiewicz, Gospodarka osadami ściekowymi, Poradnik decydenta, LEM s.c., Kraków, Poland, 1998.

[2] F. O. Kocaer, U. Alkan, and H. S. Başkaya, "The effect of alkaline-stabilized-sludge application on the microbiological quality of soil and leachate," Journal of Plant Nutrition and Soil Science, vol. 167, no. 6, pp. 704-712, 2004.

[3] M. Michałkiewicz, "Podstawowe testy biologiczne stosowane w eksploatacji oczyszczalni ścieków," in Proceedings of the Eksploatatora Forum, no. 1, 2002.

[4] B. Nørrung and S. Buncic, "Microbial safety of meat in the European Union," Meat Science, vol. 78, no. 1-2, pp. 14-24, 2008.

[5] J. Zamorska, "Organizmy patogenne w osadach ściekowych," Zeszyty Naukowe PTIE i PTG Oddziału w Rzeszowie, vol. 9, 2007.

[6] J. Bień, Osady Śclekowe TeorIa I Praktyka, Wydawnictwo Politechniki Częstochowskiej, Częstochowa, Poland, 2002.

[7] L. Sahlström, "A review of survival of pathogenic bacteria in organic waste used in biogas plants," Bioresource Technology, vol. 87, no. 2, pp. 161-166, 2003.

[8] I. L. Pepper, J. P. Brooks, and C. P. Gerba, "Pathogens in Biosolids," Advances in Agronomy, vol. 90, pp. 1-41, 2006.

[9] Y. H. Sun, Y. M. Luo, L. H. Wu, Z. G. Li, J. Song, and P. Christie, "Survival of faecal coliforms and hygiene risks in soils treated with municipal sewage sludges," Environmental Geochemistry and Health, vol. 28, no. 1-2, pp. 97-101, 2006.

[10] R. Sobczyk, "Gospodarka komunalnymi osadami ściekowymi teoria a praktyka," in Proceedings of the 6th Konferencja Naukowo-Techniczna Woda-Człowiek-Środowisko, Licheń, Poland, 2007.

[11] "Rozporządzenie Ministra Środowiska z dnia 13 lipca 2010 r. w sprawie komunalnych osadów ściekowych," Dziennik Ustaw, no. 137 , p. 924, 2010.

[12] K. Rahn, S. A. De Grandis, R. C. Clarke et al., "Amplification of an invA gene sequence of Salmonella typhimurium by polymerase chain reaction as a specific method of detection of Salmonella," Molecular and Cellular Probes, vol. 6, no. 4, pp. 271-279, 1992.

[13] R. Sobczyk and P. Kabus, "Słoneczne suszarnie osadów," in Forum Eksploatatora, no. 03, Wydawnictwo Seidel-Przywecki, 2006.

[14] http://www.neostar.com.pl/.

[15] J. Szczygieł and P. Krawczyk, "Uwarunkowania słonecznego suszenia osadów ściekowych," Gaz, Woda I TechnIka SanItarna, no. 3, pp. 30-44, 2006.

[16] M. Bux, R. Baumann, W. Philipp, T. Conrad, and W. Mühlbauer, "Class—a by solar drying recent experiences in Europe," in Proceedings of the Water Environment Federation (WEFTEC'01), pp. 309-317, Atlanta, Ga, USA, 2001, session 45.

[17] A. D. Cota, C. Figueroa, E. Espinoza et al., "Active Solar Drying of Wastewater Sludge: Physicochemical, Toxicological, and Nutrimental Characterization," México, http://www .uacj.mx/docentes/juflores/Documents/, 2007.

[18] S. Nathan and B. Clarke, SolarMix-Innovation in Drying Technology, CabWater Caboolture Shire Council, Arkwood Organic Recycling Pty, Mixwell Specialized Transport Pty, 2004.

[19] P. K. Hertwig, Seuchenhygienische Untersuchungen bei der Trocknung und Pelletierung von Klärschlamm. [Diplomarbait], Universität Hohenheim, 2004.

[20] K. Barr, M. Bux, S. Horn, and J. McLellan, "Accelerated airdrying of sewage sludge using a climate-controlled solar drying hall," http://www.thermo-system.com/, 2002.

[21] N. Ögleni and S. Özdemir, "Pathogen reduction effects of solar drying and soil application in sewage sludge," Turkish Journal of Agriculture and Forestry, vol. 34, pp. 509-515, 2010.

[22] V. L. Mathioudakis, A. G. Kapagiannidis, E. Athanasoulia, V. I. Diamantis, P. Melidis, and A. Aivasidis, "Extended dewatering of sewage sludge in solar drying plants," Desalination, vol. 248, no. 1-3, pp. 733-739, 2009.

[23] E. F. Shanahan, A. Roiko, N. W. Tindale, M. P. Thomas, R. Walpole, and D. Ipek Kurtböke, "Evaluation of pathogen removal in a solar sludge drying facility using microbial indicators," International Journal of Environmental Research and Public Health, vol. 7, no. 2, pp. 565-582, 2010. 


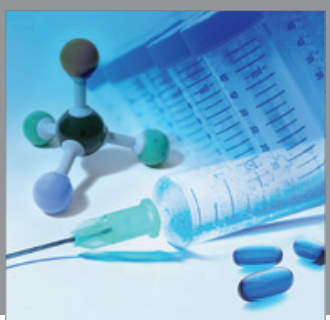

International Journal of

Medicinal Chemistry

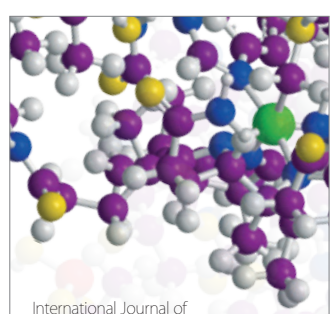

Carbohydrate Chemistry

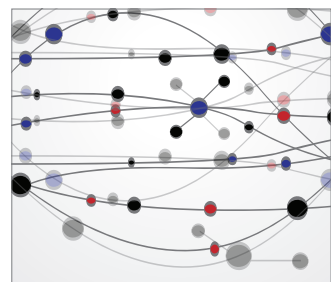

The Scientific World Journal
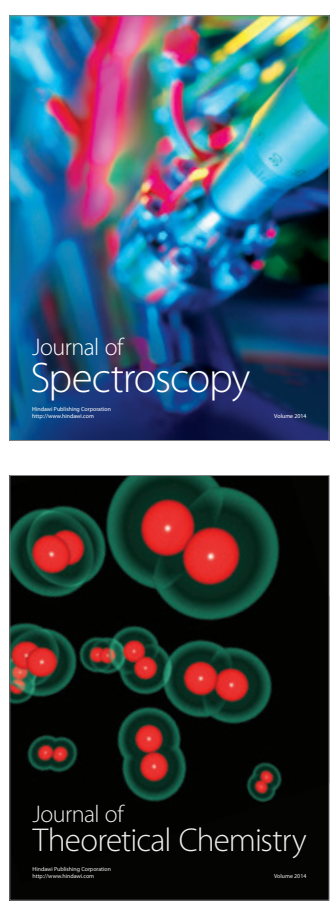
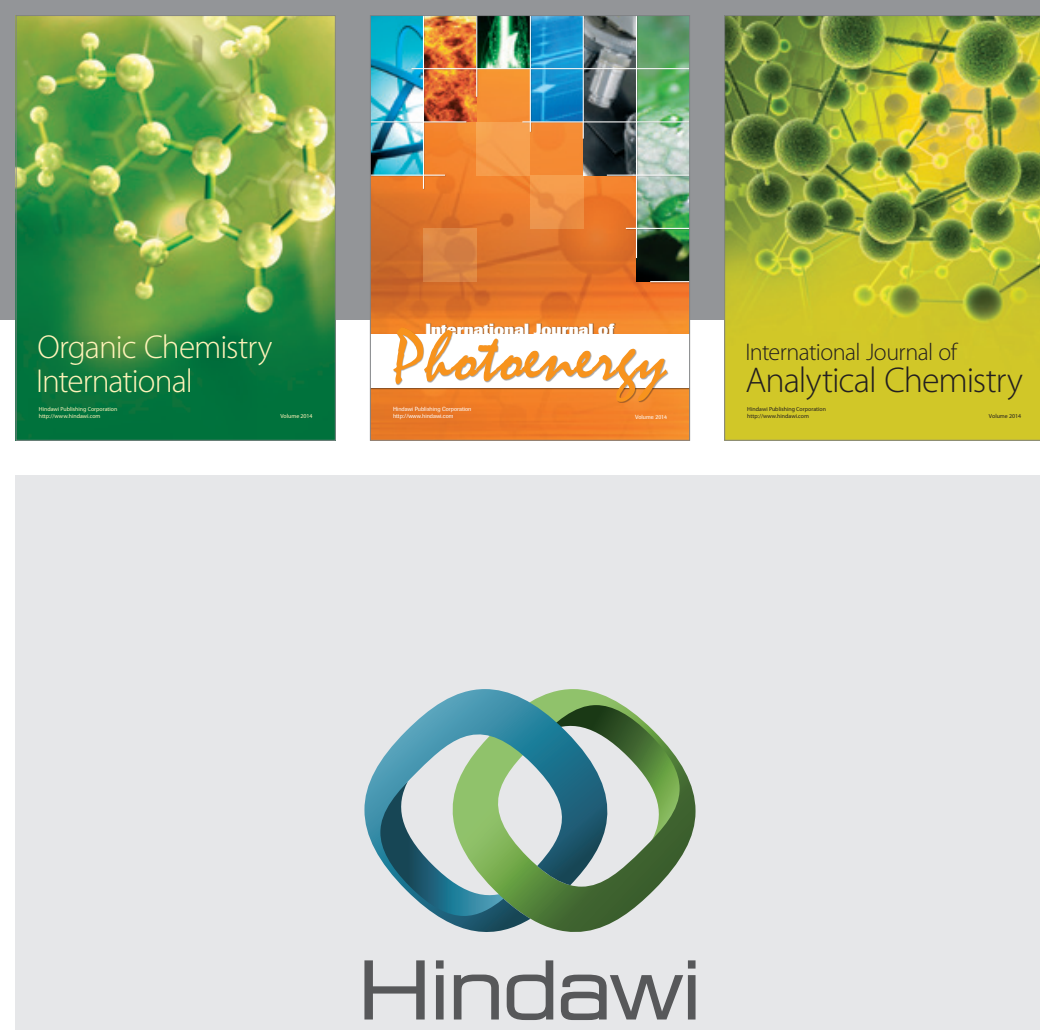

Submit your manuscripts at

http://www.hindawi.com
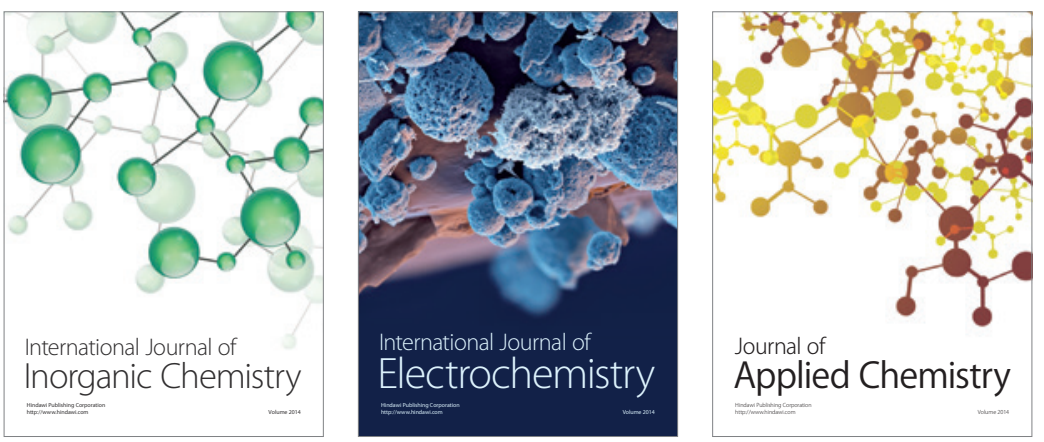

Journal of

Applied Chemistry
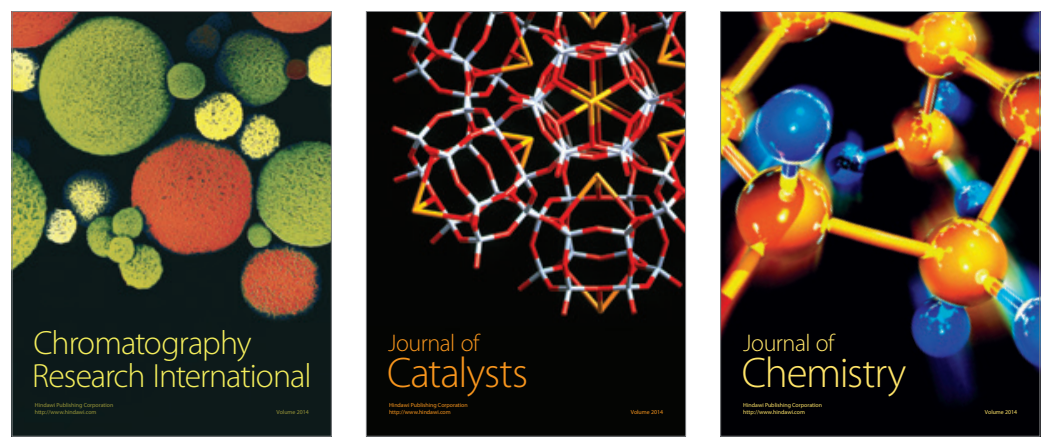
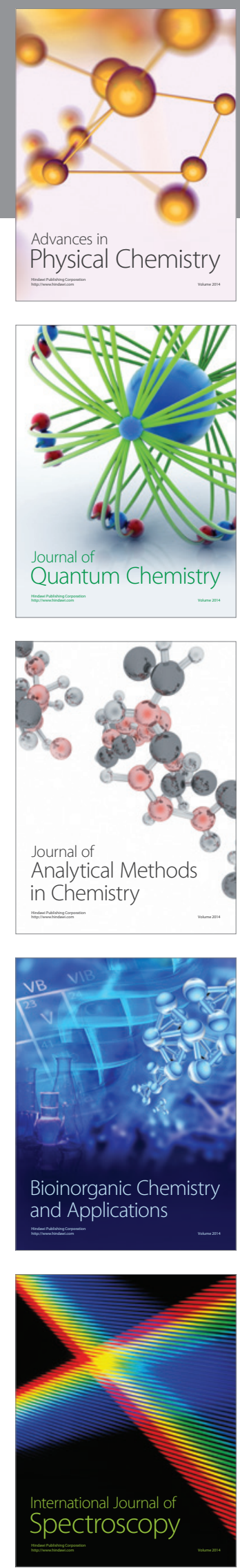